\title{
Marriage in Kanchanaburi Province, Thailand: Who Delays, Who Does Not?
}

\author{
Jidapa Phonchua ${ }^{1}$, Chai Podhisita ${ }^{2}$, Aree Jampaklay³ ${ }^{3}$ and Jongjit Rittirong ${ }^{4}$
}

Delayed marriage is a global phenomenon, but in Thailand studies addressing this issue are limited. This study aims to analyze the factors associated with delayed marriage among Thai men and women in Kanchanaburi province. The analysis is based on a sample of 1,370 men and women aged 18-59 found in the Survey of Family and Household, 2010. Chi-squared analysis reveals women are more sensitive to 'modernization variables' - education, occupation, economic status, migration experience, residential area, and attitudes towards marriage and divorce. This is confirmed by results of the logit model analysis which reveals that only age, occupation, and attitudes towards marriage have a weak-moderate effect on delayed marriage among men, whereas among women, all variables were found to be significant, with the exception of occupation. This result supports the idea that delayed marriage, particularly among women, is sensitive to modernization. It suggests that with continuing development more men and women could delay marriage. Delayed marriage could be an opportunity for more investment in human resource development aimed at preparing young adults for the family life.

Keywords delayed marriage; modernization; Kanchanaburi province; Thailand

\section{Introduction}

Marriage is regarded as an important social institution. For young adults, marriage marks the transition to adulthood characterized by new responsibility (Juntarodjana, 2002; Juntarodjana \& Podhisita, 2003). The reasons people enter into marital union may vary but usually it is to form an independent household, legitimize sexual relations and procreation, social and economic security, and rearing of offspring (Gallagher, 2002). Previous studies on marriage had addressed issues such as marriage timing, particularly postponement of marriage to a later age or delaying marriage.

In most western societies, delayed marriage is a common practice, in Asia there is a trend towards postponing marriage. Indeed, marriage pattern in Asia, including Thailand, is viewed as being in transition to getting married at older age.

The present study aims to provide a picture of delayed marriage in Kanchanaburi, a province in the western part of Thailand. The analysis addresses three specific questions: First, what is the current situation of delayed marriage in the study area? Second, who are the marriage

\footnotetext{
${ }^{1}$ Institute for Population and Social Research, Mahidol University, Thailand, Email: bui.jidapa@gmail.com

${ }^{2}$ Institute for Population and Social Research, Mahidol University, Thailand

${ }^{3}$ Institute for Population and Social Research, Mahidol University, Thailand

4 Institute for Population and Social Research, Mahidol University, Thailand
} 
delayers and who are not? Third, what are the factors that are associated with delayed marriage?

\section{Delayed Marriage in Perspective}

Gary Becker (1973) proposed an economic model to analyze marriage behavior using the utility approach which suggests marriage would occur if both partners see that by so doing they are better off

In this perspective, men and women are likely to enter into marital union if they see that benefits outweigh costs, indicating mate selection is informed by the desire to enhance the individuals gain.

Ruth Dixon (1971) proposed a framework for explaining cross-cultural variations with regards to marriage based on three variables: availability of marriageable mates, feasibility of marriage, and desirability of marriage. Availability of marriage is primarily determined by the balance of the age-sex ratio of the population at marriageable age within the same groups given the prevailing system of mate selection. Marriage may be delayed in situations where young people have greater freedom to choose their own spouse and make independent decisions.

The feasibility of marriage refers to the economic and social conditions favorable or not favorable for getting married and establishing an independent family. This involves availability of, and accessibility to, resources and source of stable income. In most societies today, a stable income is necessary before young people can begin a family. In situations where young people can rely on the extended kin group for support to start a new family, marriage may not be delayed.

The desirability of marriage refers to social pressure - which includes social rewards and sanctions - regarding being married. The social rewards may include respect, economic and social support, affection, and perceived old age security. Social sanctions may be isolation or stigma for being a bachelor/spinster or even childless beyond a certain age. If social rewards for remaining single are stronger than social sanctions, marriage is likely to be delayed.

Dixon's analysis reveals that availability of marriageable mates is not a good predictor of the age and decision regarding marriage, and that feasibility and desirability provide better clues. Many scholars have taken different aspects of modernization as key factors for understanding decisions regarding marriage. William Goode (1963, 1968) emphasizes the force of industrialization as a key factor leading to changes in the family structure. Goode's main focus is on transformation from extended to conjugal (nuclear) structure of the family. According to this perspective, the small conjugal family will be a predominant form of living arrangement as the economy becomes more industrialized. The industrial forces that make this possible include spatial, economic and social mobility, availability of extra-familial institution and individualism. Industrialization also operates to have an effect on marriage timing as in industrialized society individuals need high education, job specialization, and occupational achievement which can lead to decisions regarding marriage.

A similar theory focuses on developmental idealism as a key factor of family change and marriage behavior (Thornton, 2001). The concept of developmental idealism refers to the state of being ideologically modernized, which suggests not much change in marriage and the 
family can be expected as long as the individuals are not modernized'in their ideas. If the person believes and is motivated that individualism is more desirable than familism, that autonomy is better than authority, that independence is better than dependence, and that loved marriage is more desirable than arranged marriage, it is likely that his/her decision to marry can be postponed.

Many studies on marriage timing often take into account micro-level variables such as education, occupation, women's labor force participation, economic status, place of residence, migration experience and attitudes towards marriage and divorce. Studies in different settings have found association of these variables with delayed marriage (Caldwell et al., 1989; Hirschman, 1985; Jones, 2004; Peng, 2007; Retherford, Ogawa \& Matsukura, 2001; Smith, 1980).

\section{Delayed Marriage in Thailand}

The pattern of marriage in Thailand falls somewhere between the European pattern characterized by late marriage with high level of celibacy and the Asian pattern characterized by early and universal marriage (Hajnal, 1965). Thai marriage pattern indicated the proportion of single females in each age-group is not as high as in some European such as Sweden and not as low as some developing countries in Asia such as India (Chamratrithirong, 1984). Compared to many countries in the same region the average marriage age in Thailand is high with relatively high celibacy rate in certain subsets of the population. As such, Thailand is fairly distinctive with regard to the marriage pattern.

To determine delayed marriage in a particular population, demographers look at two indicators: timing of marriage commonly measured as singulate mean average age at marriage or SMAM 5 and proportion single in different age-groups (Podhisita et al., 2009).

In the period between 1960 and 1980 the singulate mean age at marriage (SMAM) of Thai people hardly changed. In this period, the mean age at marriage was around 25 years for males and 22 years for females. The change has become more visible after 1990 when the SMAM rose to 26 years for men and 23.5 years for women. In 2010, it continued to rise to 28.3 and 23.7 for men and women respectively. There is a fairly marked difference with regard to place of residence, regions and subsets of the population with different characteristics. As expected, the average age at marriage is higher in urban areas than in rural areas. For example, in 2010 the average age at the time of marriage in urban areas was 29.1 years for men and 25.2 years for women compared with 27.9 and 22.8 years respectively for men and women in the rural areas. Among the major regions of the country, the average age at marriage for both sexes in Bangkok was the highest (28.5 years), followed by the Central Region (26.4), the South (26.3), the North (26.1) and the Northeast (25.9).

In the past decades, delayed marriage in all age-groups has substantially increased. In 1960, only about one-fourth of males aged 25-29 were unmarried; in 2010 more than half of them (54 percent) were still single. Among females in the same age-group considerable increase is also

\footnotetext{
5 The singulate mean age at marriage (SMAM) is the average length of single life expressed in years among those who marry before age 50. It is a synthetic indicator calculated from marital status categories of men and women aged 15 to 54 at the census or survey date (United Nations, Department of Economic and Social Affairs, Population Division, 2013).
} 
observed, i.e. from 14 to 38 percent. In the older age-group of 30-34 the proportion of men and women who delayed marriage also increased, though at a lower rate. For example, among males the proportion rose from about 9 percent in 1960 to about 37 percent in 2010, and for females it was from about 7 to 24 percent. As in the case of the timing of marriage, the proportion of Thai men and women who delayed marriage varied with regard to place of residence and other characteristics (Guest \& Tan, 1994).

In this study, we examine delayed marriage in light of the modernization perspective. Our analysis utilizes selected modernization factors such as education, occupation, economic status, migration experience, residential area, and attitudes towards marriage and divorce. We want to ascertain the extent to which delayed marriage among men and women in our study area is associated with these modernization factors, and the degree of their gender relation.

\section{Data and Methodology}

\section{The research setting}

Kanchanaburi, the research site, is located about 130 kilometers West of Bangkok and shares the western borders of Myanmar. It is the third largest province in terms of the land area which consists of plains in the East and mountains in the West. The province has a mixed economy of agriculture, industry, and tourism. In recent decades, the place has begun to experience social and economic changes resulting from education, industry, tourism, and infrastructure development. In 2015, the Gross Provincial Product per capita (GPP) of Kanchanaburi was 106,303 baht, and ranked 32nd of all 76 provinces in the country, excluding Bangkok (National Economic and Social Development Board, 2017).

According to the 2010 census, Kanchanaburi's total population was 801,519 persons with an overall sex ratio of 98.8. Thirty-six (36) percent of the population lives in urban areas and 64 percent in the rural areas. The largest share of the population is ethnic Thai with some minority groups, mainly Mon, Karen and others in the hill areas. About 25 percent of the population aged 20-59 were never-married and 73 percent were ever-married. The rest are people whose marital status is unknown.

Kanchanaburi province was selected as the site for this study for its medium-size population, social and economic development, and relatively high marriage age. In 2010, the singulate mean age of marriage (SMAM) is 28 years for men and 24 years for women.

\section{Data and sampling procedure}

This analysis uses data from the Survey of Family and Household (SFH) conducted in Kanchanaburi Province by the Institute for Population and Social Research, Mahidol University in 2010. The survey employed two sets of questionnaires, one for the household and the other for individuals. The household questionnaire contained information on basic demographic characteristics of all household members, household characteristics and household economy. The individual questionnaire collects data from men and women aged 18-59 years including information on migration experience, marriage history, attitudes towards marriage and divorce, and family relationship. In this analysis, the data was drawn from selected parts of both the household and individual questionnaires. 
The SFH used most, but not all, of the same sample villages/communities in the Kanchanaburi Demographic Surveillance System project (KDSS) ${ }^{6}$. Initiated in 2000, the KDSS employed stratified sampling technique to identify the study villages/communities. First, the entire province was divided into five different zones based on geographical characteristics and dominant economic types: urban/semi-urban area, rice growing area, plantation area, upland, and mixed economy area. From these 5 zones 100 villages/communities from both rural and urban centers were randomly selected. All households in the selected villages/communities were enumerated.

The SFH drew sample from 4 of the 5 KDSS zones, that is, the upland was excluded. In these 4 zones, there were about 9,000 households in 20 urban communities and 60 rural villages. The SFH randomly selected 50 percent from these urban and rural communities/villages, of which about 10 percent of the total households were randomly selected for the SFH study. SFH slightly oversampled households from the urban areas, resulting the share of households in the SFH sample to be 40 percent from urban and 60 percent from rural areas. Of these urban and rural communities SFH randomly selected 900 households for interview: 360 from urban and 540 from rural areas.

Data collection came from face-to-face interviews. In each sample household, the household questionnaire was first administered before interviewing eligible male and female members aged 18-59, regardless of marital status, using the individual questionnaire. In case the household has more than one eligible respondent, only one male and/or one female from each broad age-group (18-29, 30-44, and 45-59) was interviewed. The maximum number of cases from a household was limited to 6 persons.

A total of 1,702 adults aged 18-59 were successfully interviewed in the SFH survey, of which 738 were male ( 43 percent) and 964 were female ( 57 percent). The smaller number of men in the sample was due largely to the fact that men were relatively harder to reach for the interview (not at home) even with two or three attempts.

\section{Eligible cases for the analysis}

Out of the 1,702 successful interviews, the age cut-point for determining whether marriage is delayed or not delayed was set at 29 for men and 24 for women.

Males and females aged equal to or younger than the age cut-point at the time of interview are not included in the analysis. Through this method 553 men and 817 women were included in this study.

\section{Definitions and statistical methods}

In this analysis, the following variables and related terms are used:

Marriage is defined as voluntary and intimate relationship that legitimizes sexual union between a man and woman. Such relationship may or may not be marked by some forms of traditional ceremonies and/or legal registration, or based purely on mutual consent of the concerned parties. As such, marriage here includes some form of cohabitation. This is based on the respondent's report at interview.

6 This project was implemented by the Institute for Population and Social Research, Mahidol University. It was supported by the Wellcome Trust Center of Excellence, UK. The demographic surveillance system was carried out annually from 2000 to 2004 in Kanchanaburi Province. 
Delayed marriage refers to voluntary postponement of first marriage to an age older than the cut-point mentioned above. Based on this definition, men who marry at any age after 29 and women who marry at any age after 24 are delayers.

Age refers to respondent's completed years of age.

Education refers to the highest level of formal education completed, not years of schooling. It is grouped into 3 categories; never attended school, any primary education, and any secondary and higher.

Occupation refers to the main economic activity by which the respondents earn income. It is divided into 3 broad categories; agriculture, non-agriculture, and not working.

Economic status is defined on the basis of monthly income (in Thai baht). It is classified into 3 groups; poor, middle, and upper, based on the poverty line of Kanchanaburi province in 2010 which was 2,428 baht. To determine which respondents are in poor, middle, or upper economic status, the average monthly income per member of the SFH households was compared with the provincial poverty line. Respondents whose income falls below the poverty line are considered poor; those above the poverty line up to 75 percent are considered middle; and those at the top 76-100 percent are considered upper economic status.

Migration experience (after age 15) refers to respondent's migration experience outside their native province for a period of one year or longer since age 15 years, and categorized into "ever-moved out" and "never-moved out".

Residential area (up to age 15) is defined as the area where the respondents lived from birth till age 15, and divided into two categories; urban area and rural area.

Attitudes towards marriage and divorce refer to the respondent's views on marriage and divorce categorized into "traditional" and "non-traditional". Traditional attitudes are social norms and customary rules as the guideline for practice regarding marriage and divorce. Nontraditional attitudes are characterized by views which favor independent and free decision based on individual interest.

To address the issue of delayed marriage in the context of the study area the analysis will first identify proportions and characteristics of men and women who delay marriage compared with those who do not. Following which the factors that are believed to influence delayed marriage are analyzed. Chi-squared test and Logistic regression (binary logit model) are used for this purpose. Separate analytical models for men and women are performed.

\section{Findings}

\section{Delayed marriage in Kanchanaburi}

Data in Table 1 show marriage patterns for men and women for the whole country and Kanchanaburi. From these patterns two observations can be made. First, for both settings the proportions of singles in each age-group suggests men and women have somewhat different schedules with regard to the timing of their marriage. For age-groups up to 20-24 (i.e. early twenties), there is not much difference; i.e. majority of men and women are still single. In other words, in early twenties delay their marriage is more or less the norm. From the late twenties (age-group of 25-29) onwards the proportion single progressively decreases. The pattern for Kanchanaburi bears some difference with the national situation. In Kanchanaburi, for both 
men and women, substantial decreases are clearly seen in the 25-29 age-group; but for the whole country they are clear only in the age-group of 30-34 and even older. Also noticeable is that the proportion of singles (i.e. delaying marriage) in Kanchanaburi is higher among females than for males from 40-44 through 55-59.

Table 1: Proportion single of men and women in Thailand and Kanchanaburi, by age-group and sex, 2010

\begin{tabular}{cccccc}
\hline \multirow{2}{*}{ Age group } & \multicolumn{2}{c}{ Whole Country ${ }^{2}$} & \multirow{2}{*}{ Age group } & \multicolumn{2}{c}{ Kanchanaburi ${ }^{2}$} \\
\cline { 2 - 3 } \cline { 5 - 5 } & Men & Women & & Men & Women \\
\hline $15-19$ & 93.1 & 85.7 & $18-19$ & 97.1 & 68.6 \\
$20-24$ & 76.6 & 59.3 & $20-24$ & 71.4 & 54.2 \\
$25-29$ & 53.4 & 38.0 & $25-29$ & 33.3 & 25.8 \\
$30-34$ & 36.1 & 23.3 & $30-34$ & 34.2 & 18.9 \\
$35-39$ & 23.6 & 14.5 & $35-39$ & 26.5 & 18.7 \\
$40-44$ & 15.2 & 10.6 & $40-44$ & 11.4 & 14.3 \\
$45-49$ & 11.1 & 9.5 & $45-49$ & 8.7 & 17.9 \\
$50-54$ & 8.4 & 8.6 & $50-54$ & 6.7 & 13.2 \\
$55-59$ & 6.4 & 7.9 & $55-59$ & 8.0 & 10.7 \\
\hline Total N & $21,994,461$ & $22,793,215$ & Total N & 738 & 964 \\
\hline
\end{tabular}

Source: ${ }^{1}$ National Statistical Office, n.d

2 Survey of Family and Household (SFH), Institute for Population and Social Research. The sample includes men and women aged 18-59.

\section{Who delays marriage, who does not?}

Table 2 presents characteristics of marriage delayers and non-delayers. Overall, 27 percent of men and 36 percent of women in the sample are identified as marriage delayers. When considered by gender and characteristics, among men, a greater proportion of marriage delayers is among those in the younger age-group. The opposite is the case for women where the proportion singles are greater in the older age-groups. Men with no education are more likely to delay marriage (36 percent) than those with primary and secondary education. For women, the reverse is the case. The highest proportion of delayers (nearly 50 percent) are among those with higher education. This confirms the finding of Guest \& Tan (1994) that higher education - college level and beyond - is associated with late marriage and celibacy among women

The difference between men and women also appears for occupation, nearly half (47 percent) of men who are not working are marriage delayers whereas it is much lower for those who work in agricultural and non-agricultural sectors. Among women, the highest proportion of delayers was found in those who work in non-agricultural sector such as business and whitecollar jobs.

In terms of economic status, it is found that the highest proportion of delayers is among men and women who can be counted as of upper economic status. The only difference is that the proportion of delayers among women is much greater than for men.

For migration experience, the highest proportion of delayers is found among the men and women who ever moved to places outside the province of their residence at least one year after age 15. Those who do not have this experience are less likely to be marriage delayers.

Similarly, the proportion of delayers are higher among those living in the urban area. The chances of delaying are much higher (52 percent) among women than for males. Men with 
non-traditional attitudes tend to be marriage delayers though with regard to divorce the proportion of men who are delayers and non-delayers are the same. However, this is not the case for women, where a greater proportion of delayers has been observed among those with non-traditional attitudes towards both marriage and divorce.

The Chi-squared test in Table 2 reveals that across all characteristics the difference between marriage delayers and non-delayers among men is statistically significant in most but not all characteristics. These include age, occupation, migration experience, place of residence and attitudes towards marriage. For women, the difference is found to be statistically significant in all characteristics except age. This leads us to an interpretation that men and women who are more exposed to modernization are more likely to be marriage delayers. The data suggests that delaying marriage for females is more sensitive to modernization factors than for males.

Table 2: Percentage distribution of men and women in Kanchanaburi who do not delay and who delay marriage, by characteristics, 2010

\begin{tabular}{|c|c|c|c|c|c|c|c|c|}
\hline \multirow[b]{2}{*}{ Characteristics } & \multicolumn{4}{|c|}{ Men } & \multicolumn{4}{|c|}{ Women } \\
\hline & $\begin{array}{r}\text { Total } \\
(\mathrm{N}) \\
\end{array}$ & $\begin{array}{r}\text { Non- } \\
\text { delayers }\end{array}$ & Delayers & $x^{2}$ & $\begin{array}{r}\text { Total } \\
(\mathrm{N}) \\
\end{array}$ & $\begin{array}{r}\text { Non- } \\
\text { delayers }\end{array}$ & Delayers & $\chi^{2}$ \\
\hline Number & 553 & 402 & 151 & & 817 & 524 & 293 & \\
\hline Percentage & 100.0 & 72.7 & 27.3 & & 100.0 & 64.1 & 35.9 & \\
\hline \multicolumn{9}{|c|}{ Population characteristics } \\
\hline Age group & & & & $11.682 * *$ & & & & 1.110 \\
\hline $25-29$ & \# & \# & \# & & $\begin{array}{l}10.4 \\
(85)\end{array}$ & $\begin{array}{l}67.1 \\
(57)\end{array}$ & $\begin{array}{l}32.9 \\
(28)\end{array}$ & \\
\hline $30-39$ & $\begin{array}{r}30.9 \\
(171)\end{array}$ & $\begin{array}{r}63.2 \\
(108)\end{array}$ & $\begin{array}{l}36.8 \\
(63)\end{array}$ & & $\begin{array}{r}25.7 \\
(210)\end{array}$ & $\begin{array}{r}65.7 \\
(138)\end{array}$ & $\begin{array}{l}34.3 \\
(72)\end{array}$ & \\
\hline $40-49$ & $\begin{array}{r}34.2 \\
(189)\end{array}$ & $\begin{array}{r}78.3 \\
(148)\end{array}$ & $\begin{array}{l}21.7 \\
(41)\end{array}$ & & $\begin{array}{r}33.4 \\
(273)\end{array}$ & $\begin{array}{r}64.1 \\
(175)\end{array}$ & $\begin{array}{l}35.9 \\
(98)\end{array}$ & \\
\hline $50-59$ & $\begin{array}{r}34.9 \\
(193)\end{array}$ & $\begin{array}{r}75.6 \\
(146)\end{array}$ & $\begin{array}{l}24.4 \\
(47)\end{array}$ & & $\begin{array}{r}30.5 \\
(249)\end{array}$ & $\begin{array}{r}61.8 \\
(154)\end{array}$ & $\begin{array}{l}38.2 \\
(95)\end{array}$ & \\
\hline Education & & & & 5.241 & & & & $36.851 * * *$ \\
\hline $\begin{array}{l}\text { Never attended } \\
\text { school }\end{array}$ & $\begin{array}{r}2.0 \\
(11)\end{array}$ & $\begin{array}{r}63.6 \\
(7)\end{array}$ & $\begin{array}{r}36.4 \\
(4)\end{array}$ & & $\begin{array}{r}7.6 \\
(62)\end{array}$ & $\begin{array}{l}77.4 \\
(48)\end{array}$ & $\begin{array}{l}22.6 \\
(14)\end{array}$ & \\
\hline Primary & $\begin{array}{r}60.0 \\
(332)\end{array}$ & $\begin{array}{r}76.2 \\
(253)\end{array}$ & $\begin{array}{l}23.8 \\
(79)\end{array}$ & & $\begin{array}{r}56.1 \\
(458)\end{array}$ & $\begin{array}{r}71.0 \\
(325)\end{array}$ & $\begin{array}{r}29.0 \\
(133)\end{array}$ & \\
\hline $\begin{array}{l}\text { Secondary or } \\
\text { higher }\end{array}$ & $\begin{array}{r}38.0 \\
(210)\end{array}$ & $\begin{array}{r}67.6 \\
(142)\end{array}$ & $\begin{array}{l}32.4 \\
(68)\end{array}$ & & $\begin{array}{r}36.3 \\
(297)\end{array}$ & $\begin{array}{r}50.8 \\
(151)\end{array}$ & $\begin{array}{r}49.2 \\
(146)\end{array}$ & \\
\hline Occupation & & & & $20.702 * * *$ & & & & $15.014 * * *$ \\
\hline Not working & $\begin{array}{r}3.4 \\
(19)\end{array}$ & $\begin{array}{l}52.6 \\
(10)\end{array}$ & $\begin{array}{r}47.4 \\
(9)\end{array}$ & & $\begin{array}{r}17.5 \\
(143)\end{array}$ & $\begin{array}{l}67.8 \\
(97)\end{array}$ & $\begin{array}{l}32.2 \\
(46)\end{array}$ & \\
\hline Agriculture & $\begin{array}{r}45.6 \\
(252)\end{array}$ & $\begin{array}{r}81.7 \\
(206)\end{array}$ & $\begin{array}{l}18.3 \\
(46)\end{array}$ & & $\begin{array}{r}42.8 \\
(350)\end{array}$ & $\begin{array}{r}70.0 \\
(245)\end{array}$ & $\begin{array}{r}30.0 \\
(105)\end{array}$ & \\
\hline Non-agriculture & $\begin{array}{r}51.0 \\
(282)\end{array}$ & $\begin{array}{r}66.0 \\
(186)\end{array}$ & $\begin{array}{l}34.0 \\
(96)\end{array}$ & & $\begin{array}{r}39.7 \\
(324)\end{array}$ & $\begin{array}{r}56.2 \\
(182)\end{array}$ & $\begin{array}{r}43.8 \\
(142)\end{array}$ & \\
\hline Economic status & & & & 2.304 & & & & $20.188 * * *$ \\
\hline Poor & $\begin{array}{r}38.2 \\
(222)\end{array}$ & $\begin{array}{r}74.9 \\
(167)\end{array}$ & $\begin{array}{l}25.1 \\
(55)\end{array}$ & & $\begin{array}{r}38.7 \\
(327)\end{array}$ & $\begin{array}{r}71.8 \\
(232)\end{array}$ & $\begin{array}{l}28.2 \\
(95)\end{array}$ & \\
\hline Middle & $\begin{array}{r}37.8 \\
(139)\end{array}$ & $\begin{array}{r}73.7 \\
(103)\end{array}$ & $\begin{array}{l}26.3 \\
(36)\end{array}$ & & $\begin{array}{r}37.2 \\
(213)\end{array}$ & $\begin{array}{r}63.8 \\
(144)\end{array}$ & $\begin{array}{l}36.2 \\
(69)\end{array}$ & \\
\hline Upper & $\begin{array}{r}24.1 \\
(192)\end{array}$ & $\begin{array}{r}67.7 \\
(132)\end{array}$ & $\begin{array}{l}32.3 \\
(60)\end{array}$ & & $\begin{array}{r}24.1 \\
(276)\end{array}$ & $\begin{array}{r}52.3 \\
(147)\end{array}$ & $\begin{array}{r}47.7 \\
(129)\end{array}$ & \\
\hline
\end{tabular}




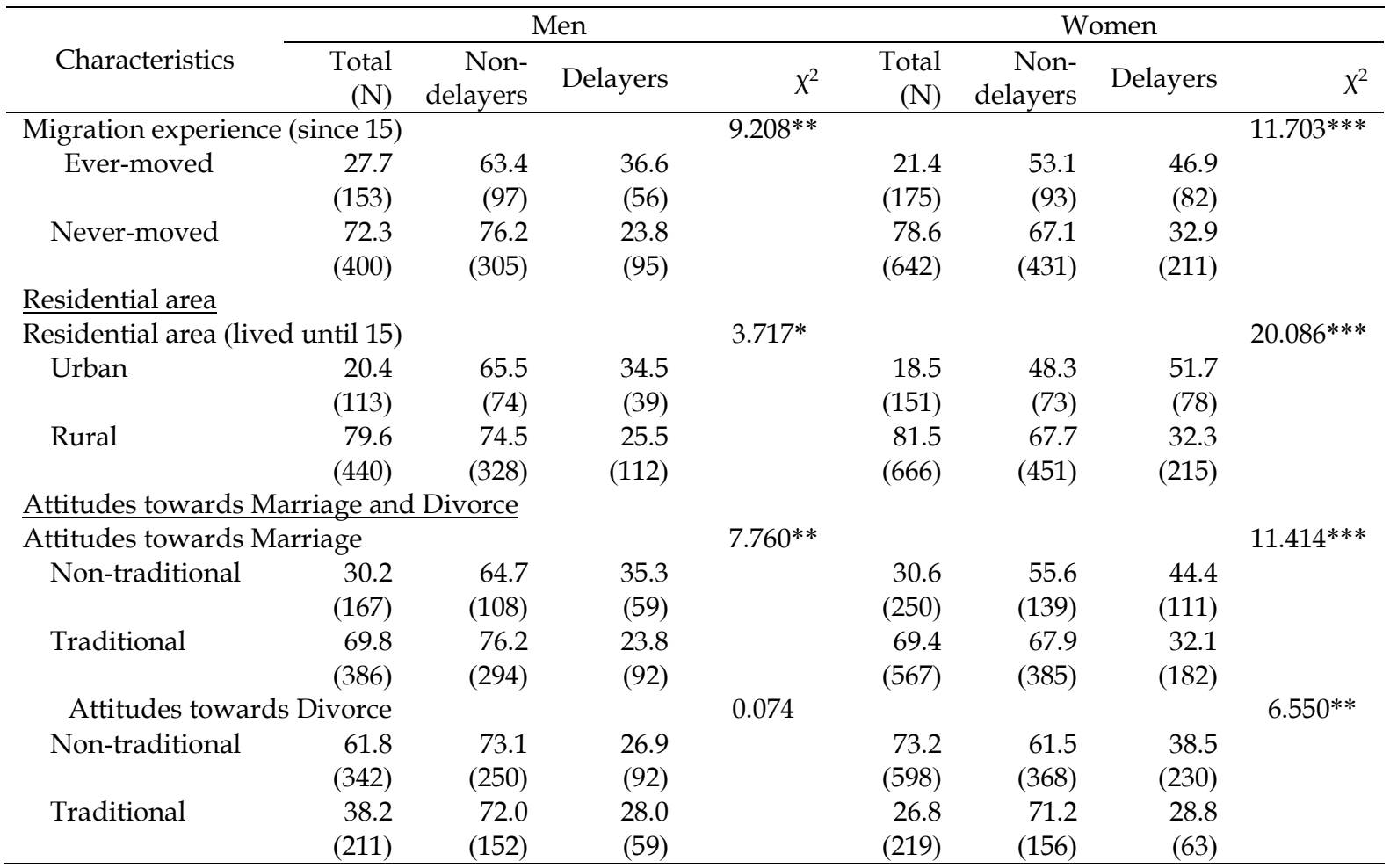

${ }^{*} p<0.05,{ }^{* *} p<0.01,{ }^{* * *} p<0.001$

\# Note: Since the age cut-point for men is 29 , so men aged 29 and younger are not included in the sample.

\section{Factors associated with delayed marriage}

From the bivariate analysis above we have some knowledge of the characteristics of individuals most likely to delay marriage. But it is not clear how modernization factors included in our list of independent variables are actually affecting delayed marriage.

Four logit models were constructed to determine effect and strength of each factor in predicting delayed marriages. Model I represents the real direct effect of age, education, occupation, and economic status on delayed marriage. In Model II migration experience is added. In Model III residential area is included, and Model IV is the full model in which all variables are included to show whether the effect of each independent variable on delayed marriage is statistically significant. The analysis above suggests reasons for delaying marriage differ between males and females, see Tables 3 (males) and Table 4 (females).

Table 3, shows that out of all factors only three are found to be statistically significant for men: age, occupation, and attitudes towards marriage. It is worth noting that the influence of age and occupation for men for all models is only moderately significant. Attitudes towards marriage shows only a weak effect. For the rest of variables, their influences on men's delayed marriage are not statistically significant.

Of the three factors which were significant, occupation had the strongest influence, followed by attitudes towards marriage and age. Men engaged in agriculture related work are 48 percent less likely to delay marriage compared to those in the non-agricultural sector. Unemployed males are 93 percent more likely to delay marriage though the influence in this case is not statistically significant, while those with traditional attitudes towards marriage are 36 percent less likely to delay marriage. Noted too was that a one-year increase in a man's age reduces the chance of delaying marriage by 3 percent. 
Table 4 shows the results for females. It may be recalled that in the Chi-squared test (Table 2) all characteristics, except age, show significant association with delayed marriage. This is more or less confirmed by the results of logit model analysis, with additional note that here age shows its moderately significant influence on delayed marriage while occupation shows an influence with no statistical significance. All other factors show their influences on delayed marriage with varying levels of statistical significance.

In terms of the strength of the influence, it can be observed that a yearly increase in a woman's age leads to a 3 percent increase in the likelihood that marriage will be delayed. A woman with no schooling is 67 percent less likely to delay marriage compared to those with secondary education or higher, while a woman with primary level education is 55 percent less likely to delay marriage compared to those with any secondary or higher. A female of poor economic status is 34 percent less likely to delay marriage compared to counterparts with high economic status. A woman who has migration experience has 68 percent higher chance of delaying marriage compared to those who do not have this experience. Women who lived in the rural areas are 33 less likely to postpone their marriage. Women with traditional attitudes towards marriage are 29 percent less likely to delay their marriage, and women with traditional attitudes towards divorce are 30 percent less likely to delay their marriage. 
Table 3: Logit model prediction of factors affecting Delayed Marriage of adult population in Kanchanaburi province, Men

\begin{tabular}{|c|c|c|c|c|c|c|c|c|c|c|c|c|}
\hline \multirow[b]{2}{*}{ Independent Variables } & \multicolumn{3}{|c|}{ Model I } & \multicolumn{3}{|c|}{ Model II } & \multicolumn{3}{|c|}{ Model III } & \multicolumn{3}{|c|}{ Model IV } \\
\hline & Beta & S.E. & $\begin{array}{l}\text { Odds } \\
\text { Ratio }\end{array}$ & Beta & S.E. & $\begin{array}{l}\text { Odds } \\
\text { Ratio }\end{array}$ & Beta & S.E. & $\begin{array}{l}\text { Odds } \\
\text { Ratio }\end{array}$ & Beta & S.E. & $\begin{array}{l}\text { Odds } \\
\text { Ratio }\end{array}$ \\
\hline Number & \multicolumn{3}{|c|}{553} & \multicolumn{3}{|c|}{553} & \multicolumn{3}{|c|}{553} & \multicolumn{3}{|c|}{553} \\
\hline -2 Log likelihood & \multicolumn{3}{|c|}{$\begin{array}{c}617.282^{*} \\
1.076\end{array}$} & \multicolumn{3}{|c|}{614.266} & \multicolumn{3}{|c|}{613.803} & \multicolumn{3}{|c|}{609.613} \\
\hline Constant & \multicolumn{3}{|c|}{1.076} & \multicolumn{3}{|c|}{0.864} & \multicolumn{3}{|c|}{0.981} & \multicolumn{3}{|c|}{1.082} \\
\hline Age & -0.036 & 0.012 & $0.965 * *$ & -0.035 & 0.012 & $0.966 * *$ & -0.035 & 0.012 & $0.965 * *$ & -0.035 & 0.012 & $0.966^{* *}$ \\
\hline \multicolumn{13}{|l|}{ Education } \\
\hline - Never attended school & 0.462 & 0.670 & 1.588 & 0.575 & 0.674 & 1.776 & 0.599 & 0.677 & 1.821 & 0.627 & 0.685 & 1.873 \\
\hline $\begin{array}{l}\text { - Primary } \\
\text { - Secondary or higher (ref.) }\end{array}$ & -0.023 & 0.220 & 0.977 & 0.021 & 0.222 & 1.021 & 0.050 & 0.227 & 1.052 & 0.082 & 0.230 & 1.086 \\
\hline \multicolumn{13}{|l|}{ Occupation } \\
\hline - Not working & 0.740 & 0.494 & 2.097 & 0.702 & 0.498 & 2.018 & 0.720 & 0.498 & 2.055 & 0.658 & 0.505 & 1.930 \\
\hline $\begin{array}{l}\text { - Agriculture } \\
\text { - Non-agriculture (ref.) }\end{array}$ & -0.779 & 0.217 & $0.459 * * *$ & -0.713 & 0.221 & $0.490 * * *$ & -0.684 & 0.225 & $0.505^{* *}$ & -0.658 & 0.228 & $0.521 * *$ \\
\hline \multicolumn{13}{|l|}{ Economic status } \\
\hline - Poor & -0.237 & 0.268 & 0.789 & -0.228 & 0.269 & 0.796 & -0.215 & 0.270 & 0.806 & -0.139 & 0.274 & 0.870 \\
\hline $\begin{array}{l}\text { - Middle } \\
\text { - Upper (ref.) }\end{array}$ & -0.234 & 0.256 & 0.791 & -0.236 & 0.257 & 0.790 & -0.221 & 0.259 & 0.802 & -0.170 & 0.261 & 0.844 \\
\hline \multicolumn{13}{|l|}{ Migration experience (since 15) } \\
\hline $\begin{array}{l}\text { - Ever-moved } \\
\text { - Never-moved (ref.) }\end{array}$ & & & & 0.380 & 0.218 & 1.463 & 0.379 & 0.218 & 1.461 & 0.409 & 0.219 & 1.505 \\
\hline $\begin{array}{l}\text { Residential area (lived until 15) } \\
\text { - Rural } \\
\text { - Urban (ref.) }\end{array}$ & & & & & & & -0.169 & 0.247 & 0.845 & -0.123 & 0.251 & 0.885 \\
\hline $\begin{array}{l}\text { Attitudes towards Marriage } \\
\text { - Traditional } \\
\text { - Non-traditional (ref.) }\end{array}$ & & & & & & & & & & -0.453 & 0.222 & $0.636^{*}$ \\
\hline $\begin{array}{l}\text { Attitudes towards Divorce } \\
\text { - Traditional } \\
\text { - Non-traditional (ref.) }\end{array}$ & & & & & & & & & & 0.154 & 0.212 & 1.167 \\
\hline
\end{tabular}

${ }^{*} p<0.05,{ }^{* *} p<0.01,{ }^{* * *} p<0.001$ 
Table 4: Logit model prediction of factors affecting Delayed Marriage of adult population in Kanchanaburi province, Women

\begin{tabular}{|c|c|c|c|c|c|c|c|c|c|c|c|c|}
\hline \multirow[b]{2}{*}{ Independent Variables } & \multicolumn{3}{|c|}{ Model I } & \multicolumn{3}{|c|}{ Model II } & \multicolumn{3}{|c|}{ Model III } & \multicolumn{3}{|c|}{ Model IV } \\
\hline & Beta & S.E. & $\begin{array}{l}\text { Odds } \\
\text { Ratio }\end{array}$ & Beta & S.E. & $\begin{array}{l}\text { Odds } \\
\text { Ratio }\end{array}$ & Beta & S.E. & $\begin{array}{l}\text { Odds } \\
\text { Ratio }\end{array}$ & Beta & S.E. & $\begin{array}{l}\text { Odds } \\
\text { Ratio }\end{array}$ \\
\hline Number & & 817 & & & 817 & & & 817 & & & 817 & \\
\hline-2 Log likelihood & & 1008.331 & & & 999.948 & & & 996.379 & & & 987.616 & \\
\hline Constant & & $-0.871^{*}$ & & & $-1.124^{* *}$ & & & -0.811 & & & -0.559 & \\
\hline Age & 0.030 & 0.009 & $1.030 * * *$ & 0.032 & 0.009 & $1.033 * * *$ & 0.030 & 0.009 & $1.030 * * *$ & 0.030 & 0.009 & $1.031 * * *$ \\
\hline Education & & & & & & & & & & & & \\
\hline - Never attended school & -1.303 & 0.363 & $0.272 * * *$ & -1.245 & 0.365 & $0.288 * * *$ & -1.149 & 0.368 & $0.317 * *$ & -1.102 & 0.372 & $0.332 * *$ \\
\hline $\begin{array}{l}\text { - Primary } \\
\text { - Secondary or higher (ref.) }\end{array}$ & -0.946 & 0.191 & $0.388 * * *$ & -0.927 & 0.192 & $0.396 * * *$ & -0.849 & 0.196 & $0.428 * * *$ & -0.789 & 0.199 & $0.455 * * *$ \\
\hline Occupation & & & & & & & & & & & & \\
\hline - Not working & -0.398 & 0.220 & 0.671 & -0.406 & 0.222 & 0.667 & -0.377 & 0.223 & 0.686 & -0.385 & 0.225 & 0.680 \\
\hline $\begin{array}{l}\text { - Agriculture } \\
\text { - Non-agriculture (ref.) }\end{array}$ & -0.226 & 0.178 & 0.797 & -0.172 & 0.180 & 0.842 & -0.101 & 0.185 & 0.904 & -0.028 & 0.188 & 0.972 \\
\hline Economic status & & & & & & & & & & & & \\
\hline - Poor & -0.399 & 0.209 & $0.671^{*}$ & -0.421 & 0.210 & $0.657^{*}$ & -0.403 & 0.211 & $0.668^{*}$ & -0.421 & 0.213 & $0.656^{*}$ \\
\hline $\begin{array}{l}\text { - Middle } \\
\text { - Upper (ref.) }\end{array}$ & -0.205 & 0.197 & 0.815 & -0.234 & 0.199 & 0.791 & -0.193 & 0.200 & 0.824 & -0.179 & 0.202 & 0.836 \\
\hline $\begin{array}{l}\text { Migration experience (since } 15 \\
\text { - Ever-moved } \\
\text { - Never-moved (ref.) }\end{array}$ & & & & 0.534 & 0.184 & $1.706^{* *}$ & 0.525 & 0.184 & $1.691 * *$ & 0.521 & 0.186 & $1.683^{* *}$ \\
\hline $\begin{array}{l}\text { Residential area (lived until } 15 \\
\text { - Rural } \\
\text { - Urban (ref.) }\end{array}$ & & & & & & & -0.390 & 0.206 & $0.677^{*}$ & -0.393 & 0.207 & $0.675^{*}$ \\
\hline $\begin{array}{l}\text { Attitudes towards Marriage } \\
\text { - Traditional } \\
\text { - Non-traditional (ref.) }\end{array}$ & & & & & & & & & & -0.340 & 0.169 & $0.712 *$ \\
\hline $\begin{array}{l}\text { Attitudes towards Divorce } \\
\text { - Traditional } \\
\text { - Non-traditional (ref.) }\end{array}$ & & & & & & & & & & -0.354 & 0.181 & $0.702 *$ \\
\hline
\end{tabular}

${ }^{*} p<0.05,{ }^{* *} p<0.01,{ }^{* \star *} p<0.001$ 


\section{Discussion}

From the bivariate analysis, we noted that across all modernization variables delayed marriage is generally greater among women. Factors contributing to this trend are education (secondary level or higher), non-agricultural employment, higher economic status, migration to places outside the home province, exposure to urban life, and non-traditional attitudes towards marriage and divorce.

Assuming that marriage delay among women is more sensitive to modernization than among men, a reason behind this may have to do with traditional practice regarding marriage. In most Asian societies, Thailand is no exception, women tend to "marry up"; that is, there is a relatively more tendency for them to look for potential partners with a higher a social status. As such, higher social status characterized by such qualifications as more education and better employment may make it relatively more difficulty for women to find potential partners of their preference. Therefore, their marriage tends to be delayed. In Kanchanaburi, a largely rural province, this may also be the case.

But why is men's delayed marriage less sensitive to modernization? Perhaps, the reverse of what is proposed above on women's delayed marriage may apply here. The fact is that men with more "modern" qualifications have relatively more advantage with regard to mate selection comparing to their women counterpart. In addition, since men tend to marry women with equal or a little lower social status, it makes it relatively more possible for them to find potential mates of their preference if they have a higher social status. As such their marriage is less frequently delayed comparing to that of women. On the contrary, men with less modern qualification have relatively less advantage regarding mate selection. For many of such men this results in delaying marriage. This seems to be what our data suggest which is consistent with result from the study by Guest \& Tan (1994). Our analysis (Table 3 above) shows that, comparing to those with secondary or higher education, men who had no schooling are 87 percent more likely to delay marriage, but if they have even primary education the likelihood that they will delay marriage is markedly reduced to only 8 percent although the association in this case is not statistically significant.

\section{Concluding Remarks}

We have demonstrated that delayed marriage is a social behavior that responds to modernization factors and that these factors seem to be more important for women than for men. Given these findings, one may ask if delayed marriage in Kanchanaburi is going to become more widespread. Assuming that social and economic development continues, i.e., people have more access to higher education, more employment outside agriculture, more mobility, and more exposure to urban life, it is hardly a question that delayed marriage will continue. It may also be possible that with higher level of modernization, the difference in delaying marriage between men and women will be reduced.

What can be gained from knowledge on delayed marriage? For individual young adults, postponing marriage means more time for them to acquire more knowledge and skills needed for their future family life. If this is supported by appropriate public policy and programs aiming to provide such knowledge and skills, greater benefits to both individuals and society can be possible. On the negative side, postponing marriage may put many young adults at 
sexual risk behavior and violence. Without effective programs, such risk behavior could end up in the costs to individuals and society.

This study is based on survey data conducted on one specific setting and at a particular time. The SFH, the source of our data, was not originally designed to study the phenomenon of delayed marriage. Future studies may benefit more from a large-scale survey covering a larger sample with more modernization variables such as exposure to the modern media, degree of being economically independent, self-esteem, and types of work. Where possible, a qualitative study may also be valuable especially in addressing certain aspects and the process of delayed marriage among men and women with different characteristics.

\section{Acknowledgement}

The authors would like to express sincere thanks to the Royal Golden Jubilee Ph.D. Program, the Thailand Research Fund, for funding support. Special thanks also go to all professors and colleagues for their guidance.

\section{References}

Becker, G.S. (1973). A theory of marriage: Part I. The Journal of Political Economy, 81(4), 813-846.

Caldwell, J.C., Gajanayake, I., Caldwell, B. \& Caldwell, P. (1989). Is marriage delay a multiphasic response to pressure for fertility decline? The case of Sri Lanka. Journal of Marriage and Family, $51(2), 337-351$

Chamratrithirong, A. (1984). Loosely-structured Thailand: The evidence from marriage culture. In A. Chamratrithirong (Ed.), Perspectives on the Thai marriage. Nakhon Pathom, Thailand: Institute for Population and Social Research, Mahidol University.

Dixon, R.B. (1971). Explaining cross-cultural variation in age at marriage and proportion never marrying. Population Studies, 25(2), 215-228.

Gallagher, M. (2002). What is marriage for? The public purposes of marriage law. Louisiana Law Review, 62(3), 773-775

Goode, W. (1963). World revolution and family patterns. New York: Free Press

Goode, W. (1968). Industrialization and family structure. In Bell Norman (Ed.), A modern introduction to the family (pp. 113-120). New York: Free Press

Guest, P. \& Tan, J. E. (1994). Transformation of marriage patterns in Thailand (IPSR Publication No. 176). Nakhon Pathom, Thailand: Institute for Population and Social Research, Mahidol University

Hajnal, J. (1965). European marriage patterns in perspective. In D.V. Glass \& D.E.C. Eversley (Eds.), Population in history: Essays in historical demography (pp. 101-143). London: Edward Arnold.

Hirschman, C. (1985). Premarital socio-economic roles and the timing of family formation: A comparative study of five Asian societies. Demography, 22(1), 35-59.

Jones, G.W. (2004). Not "when to marry" but "whether to marry": The changing context of marriage decision in East and Southeast Asia. In G. W. Jones \& K. Rmadas (Eds.), (Un)tying the knot: Ideal and reality in Asian marriage (pp. 3-56). Singapore: Asia Research Institute, National University of Singapore.

Juntarodjana, J. (2002). Family background and the transition to adulthood: Experience from Thailand and Hong Kong. (Unpublished doctoral dissertation). Faculty of Graduate Studies, Mahidol University. 
Juntarodjana, J. \& Podhisita, C. (2003). Transition from school to work: Experience of Thai and Hong Kong Youth. Journal of Population and Social Studies, 11(2), 71-94.

National Economic and Social Development Board. (2017). Gross regional and provincial product chain volume measures time series data, 1995-2015. Retrieved from http:/Www.nesdb.go.th/ewt_dl_link.php?nid=5628\&filename=gross_regional

National Statistical Office. (n.d.). The 1990 population and housing census, Whole Kingdom. Bangkok: National Statistical Office.

National Statistical Office. (n.d.). The 2010 population and housing census, Kanchanaburi. Bangkok: National Statistical Office

National Statistical Office. (n.d.). The 2010 population and housing census, Whole Kingdom. Bangkok: National Statistical Office.

Peng, T. N. (2007). Trends in delayed and non-marriage in Peninsular Malaysia. Asian Population Studies, 3(3), 243-261.

Podhisita, C., Varangrat, A., Gray, R., Vapattanawong, P., \& Chuanwan, S. (2009). пารเปลี่ยนแปลงภาวะสมรสใน ประเทศไทย พ.ศ. 2503-2543: นัต่อภาวะเจิิญพันธุ์ในอนาคต [Nuptiality change in Thailand, 1960-2000: Implication for future fertility]. Songklanakarin Journal of Social Sciences and Humanities, 15(5), 703-722.

Retherford, R. D., Ogawa, N., \& Matsukura, R. (2001). Late marraige and less marraige in Japan. Population and Development Review, 27(1), 65-101.

Smith, P.C. (1980). Asian marriage patterns in Transition. Journal of Family History, 5(1), 58-96.

Thornton, A. (2001). The developmental paradigm, reading history sideways, and family change. Demography, 38(4), 449-465.

United Nations, Department of Economic and Social Affairs, Population Division. (2013). World Fertility Report 2012. (United Nations publication). 